\title{
Synthesis and Antibacterial Activity of Some Transition Metal Complexes of Oxime, Semicarbazone and Phenylhydrazone
}

\author{
MAJED M. HANIA \\ Chemistry Department, \\ The Islamic University, Gaza P.O.Box 108 Gaza, Palestine. \\ honest_est@yahoo.com
}

Received 24 March 2009; Accepted 13 May 2009

\begin{abstract}
Co}, \mathrm{Ni}$ and $\mathrm{Cu}$ complexes have been prepared by reacting metal chloride with 4-chlorobenzaldehyde oxime, 4-methylbenzaldehyde oxime, 4-nitrobenzaldehyde oxime, 4-chlorobenzaldehyde semicarbazone, 4-methylbenzaldehyde semicarbazone, 4-nitrobenzaldehyde semicarbazone, 4-chloro benzaldehyde phenylhydrazone, 4-methylbenzaldehyde phenyl hydrazone and 4-nitrobenzaldehyde phenylhydrazone and their antibacterial activity have been studied and compared with their ligands against $E$. coli which gave significant results of activity.
\end{abstract}

Keywords: Synthesis, Transition metal complexes, Oxime, Semicarbazone, Phenylhydrazone, Antibacterial activity.

\section{Introduction}

Synthesis of various oximes, semicarbazones, phenyl hydrazones and their complexes with different transition metals are reported in the literature ${ }^{1-9}$ and found to be active as antibacterial $^{1-7}$, antitubercular ${ }^{8}$, antilepral ${ }^{10}$, antiviral ${ }^{11}$, antimalarial ${ }^{12}$ and active against certain kinds of tumours ${ }^{13,14}$. Considering the importance of such transition metal complexes and in continuation of our earlier work $^{3,6,9}$, on transition metal complexes with oxime, semicarbazone and phenylhydrazone derivatives, in the present paper, synthesis, characterization and antibacterial activity of $\mathrm{Co}(\mathrm{II}), \mathrm{Ni}$ (II) and $\mathrm{Cu}$ (II) complexes with 4chlorobenzaldehyde oxime, 4-methylbenzaldehyde oxime, 4-nitrobenzaldehyde oxime, 4-chlorobenzaldehyde semicarbazone, 4-methylbenzaldehyde semicarbazone, 4-nitro benzaldehyde semicarbazone, 4-chlorobenzaldehyde phenylhydrazone, 4-methyl benzaldehyde phenylhydrazone and 4-nitrobenzaldehyde phenylhydrazone are reported, and difference in antibacterial activity between the free ligands and complexes were studied with out any focusing on the structure of the complexes. 


\section{Experimental}

Melting points were determined in open capillaries and were uncorrected. IR spectra were recorded in $\mathrm{KBr}$ on Perkin-Elmer 883 spectrometer. All compounds gave satisfactory analysis. 4-chlorobenzaldahyde, 4-methylbenzaldahyde, 4-nitrobenzaldahyde, cobalt chloride, nickel chloride and copper chloride were obtained from sigma- Aldrich Ltd. and used without further purification. All compounds were tested for their antibacterial activity against negative E.coli bacteria at concentration of 50,100 and $200 \mu \mathrm{g} / \mathrm{disc}$ using cup-plate method ${ }^{11}$.

General method for synthesis of 4-chlorobenzaldehyde oxime (1), 4-methyl benzaldehyde oxime (2) and 4-nitrobenzaldehyde oxime(3)

4-Chlorobenzaldehyde, 4-methylbenzaldehyde or 4-nitrobenzaldehyde $(0.02 \mathrm{~mol})$ in $(15 \mathrm{~mL})$ ethanol was added to aqueous solution of hydroxylamine hydrochloride $(0.08 \mathrm{~mol})$ and sodium acetate $(0.1 \mathrm{~mol})$, the mixture was heated at $80-90{ }^{\circ} \mathrm{C}$ for 10 minutes and then left to cool, the precipitate was collected and purified by crystallization from ethanol to give compounds (1-3) as crystals, yields 54.3, 70.5 and $89.1 \%$, respectively.

General method for synthesis of 4-chlorobenzaldehyde semicarbazone (4) 4-methylbenzaldehyde semicarbazone (5) and 4-nitrobenzaldehyde semicarbazone (6)

4-Chlorobenzaldehyde, 4-methylbenzaldehyde or 4-nitrobenzaldehyde (0.02 mol) in (15 mL) ethanol was added to aqueous solution of semicarbazide hydrochloride $(0.01 \mathrm{~mol})$ and sodium acetate $(0.1 \mathrm{~mol})$, the mixture was shaken for a few minutes and then left to precipitate and was collected and purified by crystallization from ethanol to give compounds (4-6) as crystals, yield, 70.9, 73.0 and $91.5 \%$, respectively.

General method for synthesis of 4-chlorobenzaldehyde phenylhydrazone (7), 4-methyl benzaldehyde phenylhydrazone (8) and 4-nitrobenzaldehyde phenylhydrazone (9)

4-Chlorobenzaldehyde, 4-methylbenzaldehyde or 4-methylbenzaldehyde $(0.02 \mathrm{~mol})$ in $(15 \mathrm{~mL})$ ethanol was added to aqueous solution of phenylhydrazine hydrochloride $(0.03 \mathrm{~mol})$ and sodium acetate $(0.1 \mathrm{~mol})$; the mixture was heated at $80-90{ }^{\circ} \mathrm{C}$ for $4 \mathrm{~h}$ and then left to cool. The precipitate was collected and purified by crystallization from ethanol to give compounds (7-9) as crystals, yield, 78.4, 72.0 and $65.5 \%$, respectively.

General method for synthesis of Complexes of 4-chlorobenzaldehyde oxime, 4-methyl benzaldehyde oxime and 4-nitrobenzaldehyde oxime with $\mathrm{Co}(\mathrm{II}), \mathrm{Ni}(\mathrm{II})$ and $\mathrm{Cu}(\mathrm{II})$. (1a, $1 b, 1 c, 2 a, 2 b, 2 c, 3 a, 3 b, 3 c)$

4-Chlorobenzaldehyde oxime, 4-methylbenzaldehyde oxime or 4-nitrobenzaldehyde oxime $(0.002 \mathrm{~mol})$ was dissolved in $15 \mathrm{~mL}$ ethanol and was added to dissolved cobalt, nickel and copper chloride $(0.001 \mathrm{~mol})$ in $15 \mathrm{~mL}$ ethanol. The mixture was heated at $60{ }^{\circ} \mathrm{C}$ for $2 \mathrm{~h}$ and then left to cool. The precipitate was collected and purified by crystallization from ethanol to give compounds (1a, 1b, 1c, 2a, 2b, 2c, 3a, 3b, 3c) as crystals, yields, 53.1, 71.7, 50.1, 26.3, $19.1,18.0,85.7,53.2$ and $36.5 \%$, respectively.

General method for synthesis of complexes of 4-chlorobenzaldehyde semicarbazone, 4-methylbenzaldehyde semicarbazone and 4-nitrobenzaldehyde semicarbazone with $\mathrm{Co}(I I), N i(I I)$ and $C u(I I)(4 a, 4 b, 4 c, 5 a, 5 b, 5 c, 6 a, 6 b, 6 c)$

4-Chlorobenzaldehyde semicarbazone, 4-methylbenzaldehyde semicarbazone or 4-nitro benzaldehyde semicarbazone $(0.002 \mathrm{~mol})$ was dissolved in $15 \mathrm{~mL}$ ethanol and was added to dissolved cobalt, nickel and copper chloride $(0.001 \mathrm{~mol})$ in $15 \mathrm{~mL}$ ethanol. The mixture was heated at $60{ }^{\circ} \mathrm{C}$ for $2 \mathrm{~h}$ and then left to cool. The precipitate was collected and purified by 
crystallization from ethanol to give compounds $(\mathbf{4 a}, \mathbf{4 b}, \mathbf{4 c}, \mathbf{5 a}, \mathbf{5 b}, \mathbf{5 c}, \mathbf{6 a}, \mathbf{6 b}, \mathbf{6 c})$ as crystals, yield, 54.8,42.1,37.9, 29.2, 39.3, 31.0, 41.7, 31.6 and $23.8 \%$, respectively.

General method for synthesis of complexes of 4-chlorobenzaldehyde phenylhydrazone, 4-methylbenzaldehyde phenylhydrazone and 4-nitrobenzaldehyde phenylhydrazone with $\mathrm{Co}(\mathrm{II}), \mathrm{Ni}(\mathrm{II})$ and $\mathrm{Cu}(\mathrm{II})(7 \mathrm{a}, 7 \mathrm{~b}, 7 \mathrm{c}, 8 \boldsymbol{a}, 8 \boldsymbol{b}, 8 \boldsymbol{c}, 9 \boldsymbol{a}, 9 \mathrm{~b}, 9 \mathrm{c})$

4-Chlorobenzaldehyde phenylhydrazone, 4-methylbenzaldehyde phenylhydrazone or 4-nitro benzaldehyde phenylhydrazone $(0.002 \mathrm{~mol})$ was dissolved in $15 \mathrm{~mL}$ ethanol and was added to dissolved cobalt, nickel and copper chloride $(0.001 \mathrm{~mol})$ in $15 \mathrm{~mL}$ ethanol. The mixture was stirred for few minutes then the precipitate was collected and purified by crystallization from ethanol to give compounds (7a, 7b, 7c, 8a, 8b, 8c, 9a, 9b, 9c) as crystals, yields, 7.0, $15.3,22.3,40.1,21.3,93.3,14,81.7$ and $36.5 \%$, respectively.<smiles>[R]c1ccc(/C=N/O)cc1</smiles>

$1=\mathrm{Cl}, 2=\mathrm{Me}, 3=\mathrm{NO}_{2}$<smiles>[R]c1ccc(/C=N/NC(N)=O)cc1</smiles>

$4=\mathrm{Cl}, 5=\mathrm{Me}, 6=\mathrm{NO}_{2}$<smiles>Pc1ccc(/C=N/Nc2ccccc2)cc1</smiles>

$7=\mathrm{Cl}, 8=\mathrm{Me}, 9=\mathrm{NO}_{2}$

\section{Results and Discussion}

Oxime (1-3), Semicarbazone (4-6) and phenylhydrazone (7-9) and their complexes were prepared from 4-chlorobenzaldehyde, 4-methylbenzaldehyde and 4-nitrobenzaldehyde which gave a good crystalline yield. The reaction of 4-chlorobenzaldehyde, 4-methyl benzaldehyde and 4-nitrobenzaldehyde with hydroxylamine hydrochloride in methanol gave a white crystals in a high yield. And the reaction of 4-chlorobenzaldehyde, 4-methyl benzaldehyde and 4-nitrobenzaldehyde with phenylhydrazine hydrochloride in methanol gave a brown, brown and red color crystals respectively in a high yield. The reaction of 4-chlorobenzaldehyde, 4-methylbenzaldehyde and 4-nitrobenzaldehyde with semicarbazide hydrochloride in methanol gave white, white and pale yellow crystals respectively.

In the complexes, the reaction of 4-chlorobenzaldehyde oxime with cobalt chloride gave fine pale brawn crystals (1a), with nickel chloride gave fine green crystals (1b) and with cupper chloride gave fine dark brawn crystals (1c). The reaction of 4-methylbenzaldehyde oxime with cobalt chloride gave fine dark brawn crystals (2a), with nickel chloride gave fine pale green crystals $(\mathbf{2 b})$ and with cupper chloride gave fine green crystals $(\mathbf{2 c})$. The reaction of 4-nitrobenzaldehyde oxime with cobalt chloride gave fine dark green crystals (3a), with nickel chloride gave fine brown crystals (3b) and with cupper chloride gave fine green crystals (3c). The reaction of 4-chlorobenzaldehyde semicarbazone with cobalt chloride gave fine white crystals (4a), with nickel chloride gave fine green crystals (4b) and with cupper chloride gave fine green crystals (4c). The reaction of 4-methylbenzaldehyde semicarbazone with cobalt chloride gave fine white crystals $(\mathbf{5 a})$, with nickel chloride gave fine white crystals (5b) and with cupper chloride gave fine pale green crystals (5c).

The reaction of 4-nitrobenzaldehyde semicarbazone with cobalt chloride gave fine pale brown crystals $(\mathbf{6 a})$, with nickel chloride gave fine pale green crystals $(\mathbf{6 b})$ and with cupper chloride gave fine yellow crystals $(\mathbf{6 c})$. The reaction of 4-chlorobenzaldehyde phenylhydrazone with cobalt chloride gave fine brown crystals (7a), with nickel chloride gave fine dark green crystals (7b) and with cupper chloride gave fine green crystals (7c). 
The reaction of 4-methylbenzaldehyde phenylhydrazone with cobalt chloride gave fine dark yellow crystals $(\mathbf{8 a})$, with nickel chloride gave fine green crystals $(\mathbf{8 b})$ and with cupper chloride gave fine black crystals $(\mathbf{8 c})$.

The reaction of 4-nitrobenzaldehyde phenylhydrazone with cobalt chloride gave fine black crystals (9a), with nickel chloride gave fine red crystals $(\mathbf{9 b})$ and with cupper chloride gave fine red crystals (9c).

All compounds are stable at room temperature and insoluble in water. Some physical properties, analytical and spectral data of the compounds are summarized in Table 1.

Table 1. Analytical and spectral data of compounds.

\begin{tabular}{|c|c|c|c|}
\hline $\begin{array}{l}\text { Compounds } \\
\text { No. }\end{array}$ & $\begin{array}{c}\text { Compounds } \\
\text { Colour }\end{array}$ & $\begin{array}{l}\text { m.p, } \\
{ }^{\circ} \mathrm{C}\end{array}$ & Key IR band, $\mathrm{cm}^{-1}$ \\
\hline 1 & White & $92-94$ & $1600 v(\mathrm{C}=\mathrm{N}), 3190 v(\mathrm{O}-\mathrm{H})$ \\
\hline 2 & White & $50-52$ & $1594 \vee(\mathrm{C}=\mathrm{N}), 3302 \vee(\mathrm{O}-\mathrm{H})$, \\
\hline 3 & White & $108-110$ & $1595 \vee(\mathrm{C}=\mathrm{N}), 3190 \vee(\mathrm{O}-\mathrm{H})$ \\
\hline 4 & White & $218-220$ & $1580 \vee(\mathrm{C}=\mathrm{N}), 3320 \vee(\mathrm{N}-\mathrm{H})$ \\
\hline 5 & White & $214-216$ & $1610 v(\mathrm{C}=\mathrm{N}), 3325 v(\mathrm{~N}-\mathrm{H})$ \\
\hline 6 & Pale yellow & $222-224$ & $1605 v(\mathrm{C}=\mathrm{N}), 3315 v(\mathrm{~N}-\mathrm{H})$ \\
\hline 7 & Pale brawn & $110-112$ & $1600 v(\mathrm{C}=\mathrm{N}), 3430 v(\mathrm{~N}-\mathrm{H})$ \\
\hline 8 & Pale brawn & $110-112$ & $1610 v(\mathrm{C}=\mathrm{N}), 3450 v(\mathrm{~N}-\mathrm{H})$ \\
\hline 9 & Red & $174-176$ & $1600 v(\mathrm{C}=\mathrm{N}), 3420 v(\mathrm{~N}-\mathrm{H})$ \\
\hline $\mathbf{1 a}$ & Pale brawn & $190-192$ & $1590 v(\mathrm{C}=\mathrm{N}), 3180 v(\mathrm{O}-\mathrm{H})$ \\
\hline 1b & Green & $103-105$ & $1585 v(\mathrm{C}=\mathrm{N}), 3175 v(\mathrm{O}-\mathrm{H})$ \\
\hline 1c & Dark green & $180-182$ & $1570 v(\mathrm{C}=\mathrm{N}), 3170 v(\mathrm{O}-\mathrm{H})$ \\
\hline $2 \mathbf{a}$ & Dark brawn & $190-192$ & $1595 v(\mathrm{C}=\mathrm{N}), 3185 v(\mathrm{O}-\mathrm{H})$ \\
\hline $2 b$ & Pale green & $76-78$ & $1585 v(\mathrm{C}=\mathrm{N}), 3152 v(\mathrm{O}-\mathrm{H})$ \\
\hline $2 c$ & Green & $>300$ & $1590 v(\mathrm{C}=\mathrm{N}), 3180 v(\mathrm{O}-\mathrm{H})$ \\
\hline $\mathbf{3 a}$ & Dark green & $226-228$ & $1595 v(\mathrm{C}=\mathrm{N}), 3190 v(\mathrm{O}-\mathrm{H})$ \\
\hline 3b & Brown & $>300$ & $1600 v(\mathrm{C}=\mathrm{N}), 3150 v(\mathrm{O}-\mathrm{H})$ \\
\hline 3c & Green & $134-136$ & $1580 \vee(\mathrm{C}=\mathrm{N}), 3170 v(\mathrm{O}-\mathrm{H})$ \\
\hline $4 \mathbf{a}$ & White & $>300$ & $1589 v(\mathrm{C}=\mathrm{N}), 3312 v(\mathrm{~N}-\mathrm{H})$ \\
\hline 4b & Green & $>300$ & $1580 \vee(\mathrm{C}=\mathrm{N}), 3155 \vee(\mathrm{N}-\mathrm{H})$ \\
\hline $4 c$ & Green & 194-196 & $1585 v(\mathrm{C}=\mathrm{N}), 3260 v(\mathrm{~N}-\mathrm{H})$ \\
\hline $5 \mathbf{a}$ & White & $230-232$ & $1595 v(\mathrm{C}=\mathrm{N}), 3315 v(\mathrm{~N}-\mathrm{H})$ \\
\hline $5 \mathbf{b}$ & White & $224-226$ & $1580 \vee(\mathrm{C}=\mathrm{N}), 3152 \vee(\mathrm{N}-\mathrm{H})$ \\
\hline $5 c$ & Pale green & $218-220$ & $1592 v(\mathrm{C}=\mathrm{N}), 3265 v(\mathrm{~N}-\mathrm{H})$ \\
\hline $6 \mathbf{a}$ & Pale brown & $264-266$ & $1598 v(\mathrm{C}=\mathrm{N}), 3320 v(\mathrm{~N}-\mathrm{H})$ \\
\hline 6b & Pale green & $246-248$ & $1600 v(\mathrm{C}=\mathrm{N}), 3160 v(\mathrm{~N}-\mathrm{H})$ \\
\hline $6 c$ & Yellow & $260-262$ & $1590 v(\mathrm{C}=\mathrm{N}), 3245 v(\mathrm{~N}-\mathrm{H})$ \\
\hline $7 \mathbf{a}$ & Brown & $180-182$ & $1590 v(\mathrm{C}=\mathrm{N}), 3320 v(\mathrm{~N}-\mathrm{H})$ \\
\hline $7 b$ & Dark green & $244-246$ & $1580 \vee(\mathrm{C}=\mathrm{N}), 3160 \vee(\mathrm{N}-\mathrm{H})$ \\
\hline 7c & Green & $158-160$ & $1590 v(\mathrm{C}=\mathrm{N}), 3270 v(\mathrm{~N}-\mathrm{H})$ \\
\hline $8 \mathbf{a}$ & Dark yellow & $>300$ & $1595 v(\mathrm{C}=\mathrm{N}), 3315 v(\mathrm{~N}-\mathrm{H})$ \\
\hline $\mathbf{8 b}$ & Green & $74-76$ & $1575 v(\mathrm{C}=\mathrm{N}), 3145 v(\mathrm{~N}-\mathrm{H})$ \\
\hline $8 c$ & Black & $130-132$ & $1590 v(\mathrm{C}=\mathrm{N}), 3265 v(\mathrm{~N}-\mathrm{H})$ \\
\hline $9 \mathbf{a}$ & Black & $245-247$ & $1595 v(\mathrm{C}=\mathrm{N}), 3323 v(\mathrm{~N}-\mathrm{H})$ \\
\hline 9b & Red & $146-148$ & $1580 \vee(\mathrm{C}=\mathrm{N}), 3150 v(\mathrm{~N}-\mathrm{H})$ \\
\hline $9 c$ & Red & $212-214$ & $1590 v(\mathrm{C}=\mathrm{N}), 3240 v(\mathrm{~N}-\mathrm{H})$ \\
\hline
\end{tabular}


The infrared spectra of free ligands (1-3) show broad bands at 3190, 3302 and $3190 \mathrm{~cm}^{-1}$, which correspond to $v(\mathrm{O}-\mathrm{H})$ of oxime. The IR spectra of all the complexes $(\mathbf{1 a - 3 c})$ show downshift in $v(\mathrm{O}-\mathrm{H})$ of oxime by about $10-150 \mathrm{~cm}^{-1}$. This may be due to coordinate bond formation through oxygen of hydroxyl group ${ }^{15}$. The infrared spectrum of ligands (1-3) show bands at $c a$. 1600, 1594 and $1595 \mathrm{~cm}^{-1}$, which may be due to $v(\mathrm{C}=\mathrm{N})$ of oxime. IR spectra of all the complexes show down shift $v(\mathrm{C}=\mathrm{N})$ of oxime by $10-25 \mathrm{~cm}^{-1}$. This may be due to coordinate bond formation through nitrogen of oximino group ${ }^{16}$.

IR spectra of ligands (4-6) show bands at 3320, 3325 and $3315 \mathrm{~cm}^{-1}$ which can be assigned to $v(\mathrm{~N}-\mathrm{H})$ of imino group ${ }^{17}$. The spectra of all the complexes show down shift $v(\mathrm{~N}-\mathrm{H})$ of imino group to the $3312-3155 \mathrm{~cm}^{-1}$ The next IR band of structurals significance in the spectra of the ligands appears at 1580,1610 and $1605 \mathrm{~cm}^{-1}$. These bands can be assigned to the $v(\mathrm{C}=\mathrm{N})$ groups. These bands have also down shift to the $1600-1580 \mathrm{~cm}-1$ and clearly indicates the coordination of nitrogen to the metal ion.

IR spectra of ligands (7-9) show broad bands at 3430, 3450 and $3420 \mathrm{~cm}^{-1}$ which can be assigned to $v(\mathrm{~N}-\mathrm{H})$ groups. These bands have also down shift to the $3323-3145 \mathrm{~cm}^{-1}$ and clearly indicates the coordination of nitrogen to the metal ion. The next IR band of structural significance in the spectra of the ligands appear at 1600,1610 and $1600 \mathrm{~cm}^{-1}$. These bands can be assigned to the $v(C=N)$ group. These bands have also down shift to the $1590-1575 \mathrm{~cm}^{-1}$ and clearly indicates the coordination of nitrogen to the metal ion. On the basis of the above discussions, it's clear that the complexation of the free ligands and the transition metals have been formed.

Most of oxime (1-3) was found to possess moderate antibacterial activity at concentration $100 \mu \mathrm{g}$ while semicarbazone $(\mathbf{5})$ and phenylhydrazone $(\mathbf{7 , 8})$ gave poor antibacterial activity except those compounds which has strong electron withdrawing groups. Suggestions are made that the negative inductive effect plays a significant role, dimerization of oxime involves the formation of a pair of $\mathrm{H}$ bonds ${ }^{18}$ (Scheme 1). This feature will cause a decrease of electronic density in oximes compared with semicarbazones and phenylhydrazones, thereby facilitating entry of the oxime into the cell. This is likely to increase the antibacterial potency.

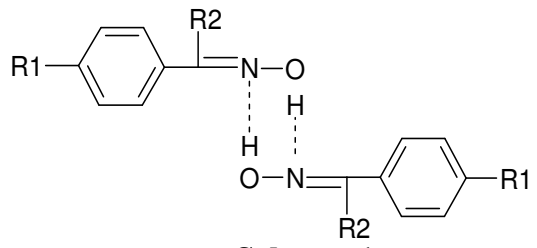

Scheme 1.

Most of ligands and complexes were found to possess moderate antibacterial activity at concentration $200 \mu \mathrm{g}$ except those free ligands which has electron donating groups, This means that compounds with high electron density gave poor antibacterial activity which makes the diffusion of these compounds more difficult throw the body of the bacteria cell ${ }^{19}$. A comparative study of the ligands and their complexes as antibacterial active indicates that the metal complexes are more active than the free ligands (Table 2).

The increase in antibacterial activity is due to faster diffusion of the free ligands with electron withdrawing groups and metal complexes as a whole through the cell membrane or due to the combined activity effect of ligand and metal ${ }^{20}$. Such increased activity of the metal chelates can be explained as polarity of the metal ion will be reduced to a greater extent due to the overlap of the ligand orbital and partial sharing of the positive charge of the metal ion with electron releasing groups. It is obvious that the reducing the total electron density on free ligands make the diffusion faster through the bacteria cell. 
Table 2. Antibacterial activity of compounds.

\begin{tabular}{|c|c|c|c|}
\hline $\begin{array}{c}\text { Compound } \\
\text { no. }\end{array}$ & $50 \mu \mathrm{g}$ & $100 \mu \mathrm{g}$ & $200 \mu \mathrm{g}$ \\
\hline 1 & -ve & $+\mathrm{ve}$ & $+\mathrm{ve}$ \\
\hline 2 & -ve & $+\mathrm{ve}$ & $+v e$ \\
\hline 3 & -ve & $+\mathrm{ve}$ & $+\mathrm{ve}$ \\
\hline 4 & -ve & $+\mathrm{ve}$ & $+v e$ \\
\hline 5 & -ve & -ve & -ve \\
\hline 6 & -ve & $+v e$ & $+v e$ \\
\hline 7 & -ve & -ve & $+v e$ \\
\hline 8 & -ve & -ve & -ve \\
\hline 9 & -ve & $+\mathrm{ve}$ & $+v e$ \\
\hline $1 \mathbf{a}$ & -ve & +ve & $+v e$ \\
\hline $1 b$ & -ve & $+\mathrm{ve}$ & $+v e$ \\
\hline 1c & -ve & $+\mathrm{ve}$ & $+v e$ \\
\hline $2 a$ & -ve & $+v e$ & $+v e$ \\
\hline $2 b$ & -ve & $+\mathrm{ve}$ & $+\mathrm{ve}$ \\
\hline $2 c$ & -ve & $+v e$ & $+v e$ \\
\hline 3a & -ve & $+\mathrm{ve}$ & $+\mathrm{ve}$ \\
\hline $3 b$ & -ve & +ve & $+v e$ \\
\hline $3 c$ & -ve & $+\mathrm{ve}$ & $+v e$ \\
\hline $4 a$ & -ve & +ve & $+v e$ \\
\hline $4 b$ & -ve & $+\mathrm{ve}$ & $+\mathrm{ve}$ \\
\hline $4 c$ & -ve & $+\mathrm{ve}$ & $+v e$ \\
\hline $5 a$ & -ve & -ve & $+v e$ \\
\hline $5 b$ & -ve & -ve & $+v e$ \\
\hline $5 c$ & -ve & -ve & $+v e$ \\
\hline $6 a$ & -ve & $+v e$ & $+v e$ \\
\hline 6b & -ve & $+\mathrm{ve}$ & $+v e$ \\
\hline $6 c$ & -ve & $+\mathrm{ve}$ & $+\mathrm{ve}$ \\
\hline $7 a$ & -ve & $+\mathrm{ve}$ & $+v e$ \\
\hline $7 b$ & -ve & $+\mathrm{ve}$ & $+v e$ \\
\hline $7 c$ & -ve & $+\mathrm{ve}$ & $+\mathrm{ve}$ \\
\hline $8 a$ & -ve & -ve & $+v e$ \\
\hline $8 \mathbf{b}$ & -ve & +ve & $+v e$ \\
\hline $8 c$ & -ve & -ve & $+v e$ \\
\hline $9 a$ & -ve & -ve & $+\mathrm{ve}$ \\
\hline $9 b$ & -ve & -ve & $+\mathrm{ve}$ \\
\hline $9 c$ & -ve & $+\mathrm{ve}$ & $+\mathrm{ve}$ \\
\hline
\end{tabular}

\section{Conclusion}

Oximes (1-3), semicarbazones (4-6) and phenyl hydrazones (7-9) have been synthesized from 4-chlorobenzaldehyde, 4-methylbenzaldehyde and 4-nitrobenzaldehyde and used as ligands in formation of complexes of $\mathrm{Co}, \mathrm{Ni}$ and $\mathrm{Cu}$, which show satisfactory antibacterial activity against -ve $E$ coli, in complexes but poor antibacterial activity against -ve $E$ coli, in case of some free ligands. This might come from the difference in total electron density between the mentioned compounds. By means that some ligands have higher electron density than complexes which prevents the inhabitation throw the body of the bacteria. 
This have been supported our earlier work, by means that the higher electron density compound the lower antibacterial active.

\section{Acknowledgments}

The author is grateful to the analytical sector staff and Islamic University for their help.

\section{References}

1. Desai J J, Desai P G and Mehta A G, Asian J Chem., 1999, 11, 519.

2. Desai J J, Desai P G and Mehta A G, Asian J Chem., 2000, 12, 1067.

3. Hania M M, Asian J Chem., 2002, 14, 1074.

4. Rai B K, Asian J Chem., 2002, 14, 1595.

5. Rai B K, Asian J Chem., 2002, 14, 312.

6. Hania M M, Asian J Chem., 2005, 17, 439.

7. Dobeck A S and Klayman D, Antimicrob Agents Chemother., 1980, 18, 27.

8. Wagner W H and Winkelman E, Arzneim Forschi, 1972, 22, 1713.

9. Hania M M, Asian J Chem., 2007, 17, 439.

10. Morrison N E and Collins F M, Int J Leprosy, 1981, 49, 180.

11. Jones D H, Slack R and Squires S, J Med Chem, 1965, 2, 676.

12. Klayman D L and Joseph F, J Med Chem., 1979, 22, 855.

13. Bauer D J, Vincent L S, Kempe C H and Dowine A W, Lancet, 1963, 2, 494.

14. Petering H G, Buskik H H and Underwood G E, Cancer Res., 1963, 64, 367.

15. Rana A K, Dabhi H R and Pancholi A M, J Polymer Mater., 1998, 41, 235.

16. Rana A K and Shah J R, Indian J Chem., 1981, 20A, 142.

17. Patil M S and Shah J R, J Indian Chem Soc., 1981, 58, 944.

18. Ling G N, Physiological Chemistry and Physics and Medical, NMR, 1986, 18.

19. Hania M M, Mater Sci Res., (India), 2006, 4, 1.

20. Raman N and Ravichandran S, Asian J Chem., 2002, 14, 1551. 


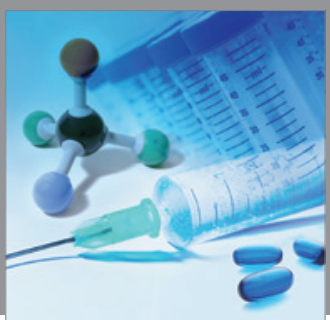

International Journal of

Medicinal Chemistry

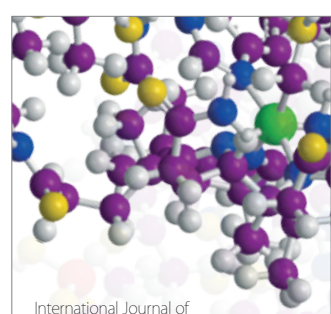

Carbohydrate Chemistry

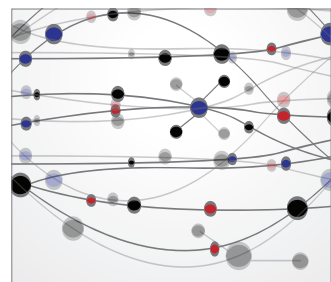

The Scientific World Journal
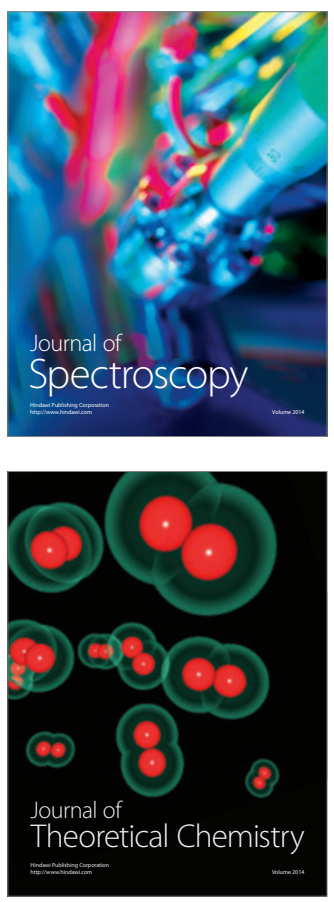
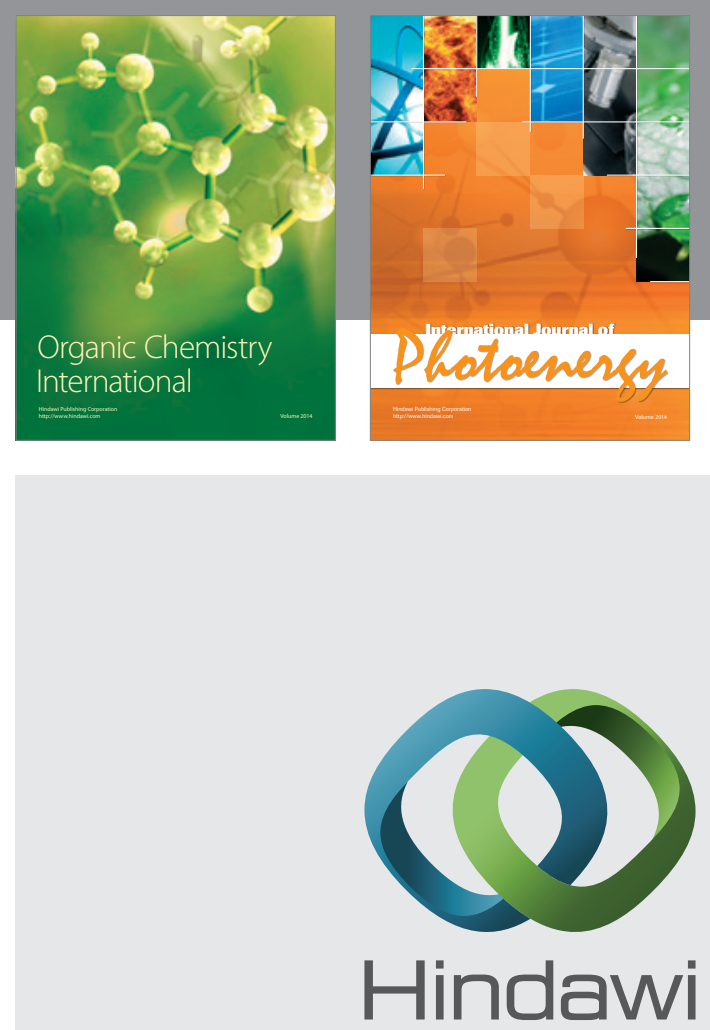

Submit your manuscripts at

http://www.hindawi.com
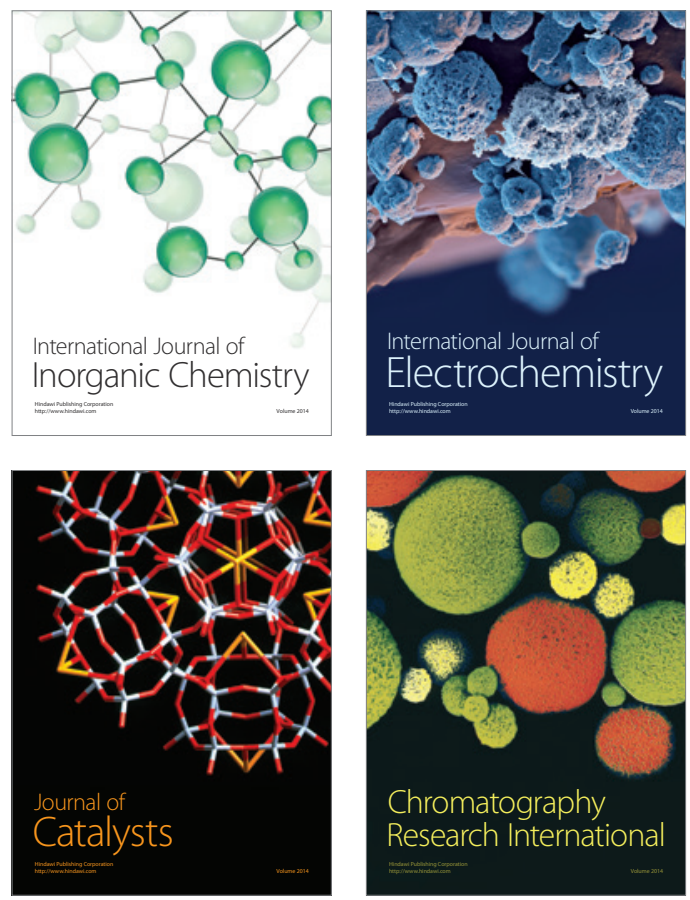
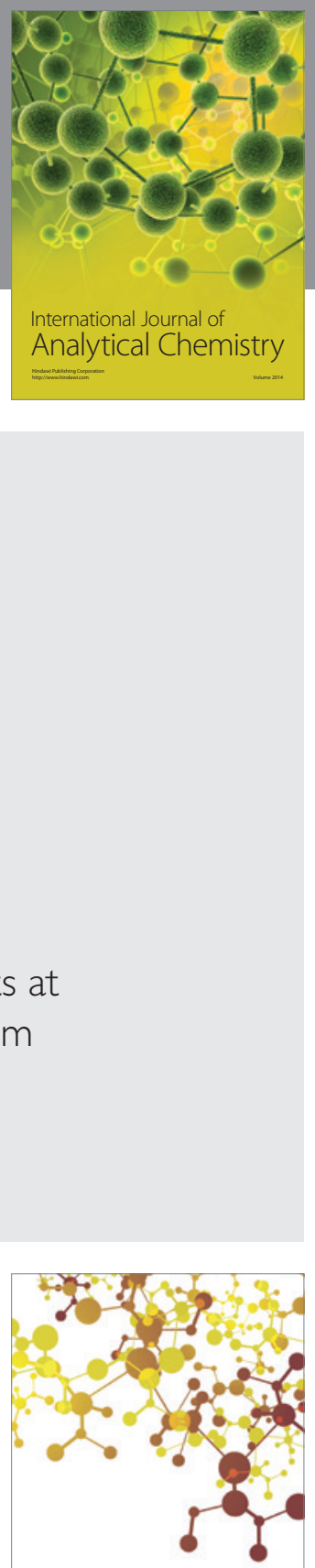

Journal of

Applied Chemistry
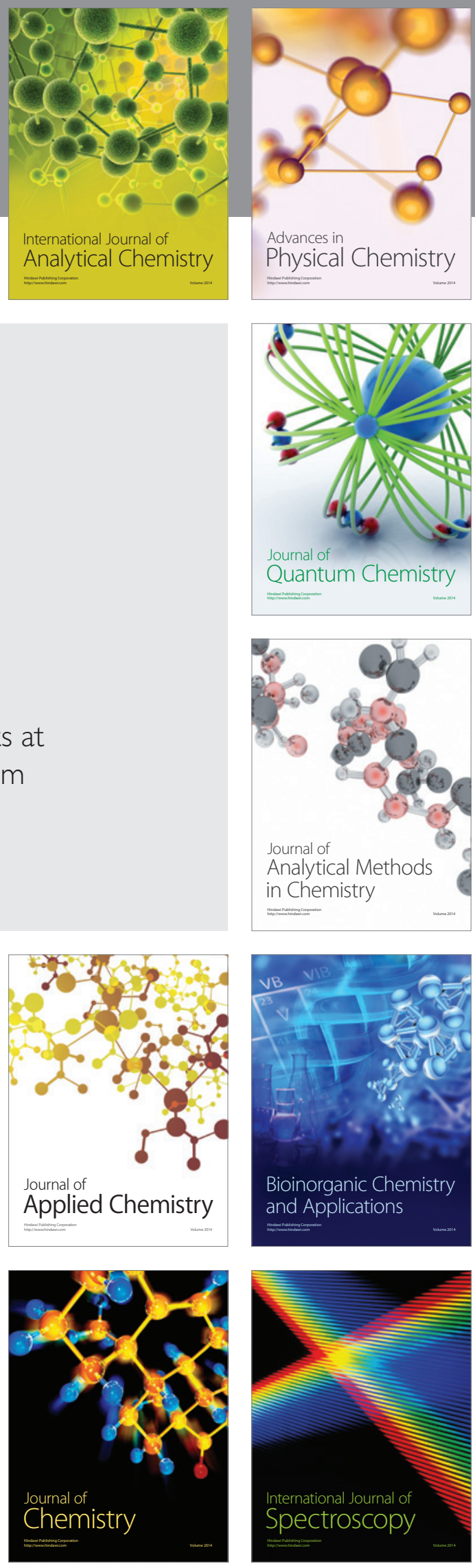